\title{
Bulk Sales Problems in California
}

\author{
David D. Ring*
}

When a California retail nerchant seeks to dispose of his stock in trade and trade equipment in conjunction with going out of business, a number of laws pertaining to "bulk" sales may be brought to bear." The major purpose of these laws, as is the case with bulk sales laws generally, is to afford the merchant's creditors an opportunity to satisfy their claims before the merchant can transfer his assets to a bona fide purchaser and vanish with the proceeds of the sale. ${ }^{2}$ This article will consider some of the problems created by these laws in operation in California and certain desirable changes therein, including the changes proposed by enactment in Califorma of the Uniforn Commercial Code.

The law generally thought of as the California bulk sales law now appears in Section 3440.1 of the California Civil Code, which provides that:

[Any transfer] of a stock in trade, in bulk, or a substantial part thereof, other than in the ordinary course of trade and in the regular and usual practice and method of business of the ... transferor ... and the ... transfer ... or inortgage of the fixtures or store equipment of a baker, cafe or restaurant owner, garage owner, machinist, cleaner and dyer, or retail or wholesale merchant, is conclusively presuned fraudulent and void as against the existing creditors of the ... transferor ... or mortgagor, unless before the consummation of the ... transfer . . . or mortgage, the ... transferor ... or mortgagor, or the intended ... transferee ... or mortgagee does all of the following:

(a) Records at least ten days before the consummation of the ... transfer ... or mortgage, in the office of the county recorder in the county or counties in which the stock in trade, fixtures, or equipment are situated, a notice of the intended ... transfer ... or inortgage, which states the name and address of the intended ... transferor ... or mortgagor and the name and address of the intended ... transferee ... or mortgagee. The notice shall contain a general statement of the character of the inerchandise or property intended to be ... transferred or nortgaged, and show the date and place where the purchase price or consideration is to be paid.

(b) Publishes at least once a copy of the notice in a newspaper of general circulation published in the judicial district in which the stock in trade,

* Member, San Francisco Bar.

1 The laws which are to be considered are Cax. Crv. Code $\$ 3440.1$, CAL. REv. \& TAx CodE $\S \S 6811,6812$, CAL. UNEMrPL. INs. CoDE $\$ \S 1731,1732$, and similar mumicipal ordinances hereinafter noted.

2 Untrorar Comarercial Code, Official Draft, Text and Comaments Edition, Comment, Purpose 4, p. 539 (1952); Weintraub and Levin, Bulk Sales Laws and Adequate Protection of Creditors, 65 HaRv. I. REv. 418 (1952). 
fixtures, or equipment are situated ... The publication shall be completed not less than five days before the date of the intended ... transfer . . . or mortgage ....$^{3}$

Section 3440.1 obviously applies to wholesalers, as well as retailers, and to certain specified merchants selling services, as well as to those selling commodities. The problems to be discussed, however, are primarily those of the seller of goods at retail. It is also true that, where the seller is solvent and proceeds in good faith to discharge all of his obligations, or where they are assumed and ultimately discharged by the buyer, the problems under discussion largely resolve themselves. Present concern is thus with the retail seller who is not able or does not desire to effect payment of his creditors' claims in full.

This by no means renders this discussion academic. In the fiscal year 1948, almost $34 \%$ of the state's retail sellers paid between $\$ 30$ and $\$ 199.99$ (both inclusive) in sales taxes in each calendar quarter, showing, at the then tax rate of $3 \%,{ }^{4}$ annual gross receipts of only $\$ 4,000$ to $\$ 26,665 . .^{5}$ In 1950 sales tax accounts were closing out at a rate estimated by the State Board of Equalization to be 10,000 each month. ${ }^{6}$ It seems sound to assume that a substantial number of these close-outs were small accounts which traditionally are most likely to be operating financially close to the margin. The increased availability of goods since 1950 has, if anything, strengthened the justification for the assumption that a substantial number of retail businesses sold out are in financial distress. ${ }^{7}$ There is thus a considerable field of commercial activity within the scope of this article.

3 Cal. Civ. Code $\$ 3440.1$. Although in many respects the requirement that the sale be "other than in the ordinary course of trade, etc." may be said to flow from the requirement that it be "in bulk" [see Walbrun v. Babbitt, 83 U.S. 577 (1872)], the former term is qualitative in meaning, while the latter is quantitative. Bilhig and Branch, The Problem of Transfers Under Bulk Sales Laws: A Study of Absolute Transfers and Liquidating Trusts, 35 MicH. L. Rev. 732 (1937). This raises some question as to the, significance, if any, of the phrase "substantial part thereof." [Originally this read "such a quantity ... as to be substantially a whole"; the present language was adopted in 1917. See notes to CaI. Crv. Code $\$ 3440$ (1927).] The decisions in Schainman v. Dean, 24 F.2d 475 (9th Cir. 1928), Markwell \& Co. v. Lynch, 114 F.2d 373 (9th Cir. 1940), noted in 41 CoL. L. Rev. 325 (1941), and Jubas v. Sampsell, 185 F.2d 333 (9th Cir. 1950 ), suggest that neither it nor the phrase "in bulk" imposes a very bigh quantitative requirement.

4 Cal. Rev. AND TaX. Code $\$ 6051$ (1939).

5 Report of the Senate Interma Concmittee on State and Local Taxation, Part 3 at $50-51$ (1951).

6 Id. at 58.

7 In addition, frequent statements appear in the texts that the very fact of the bulk sale is suggestive, at least, that the seller is in financial difficulty. Glenn has described the bulk sale as a "harhinger of travel abroad, - the proceeds of sale going with the voyager." 1 GLENN, FrAUdulent Conveyances and Preferences 537 (1940). 
A

\section{EVOLUTION OF BULK SAIES LAWS GENERALIY}

The inception and evolution of bulk sales laws generally has been extensively examined elsewhere, ${ }^{8}$ and, for present purposes, it will be sufficient to divert to historical matters only long enough to reflect the California act in the context of the bulk sales laws now existing in each of the fortyeight states and the District of Columbia.

The bulk sales law was conceived to fill a gap in the protection afforded to creditors under the existing law of fraudulent conveyances. The early English statute law relating to fraudulent conveyances, ${ }^{9}$ and its successors in the United States ${ }^{10}$ provided that a conveyance by a fraudulent transferor could be set aside only where the transferee at least had knowledge of the transferor's "purpose and intent, to delay, hinder or defraud creditors." 11 The creditor therefore faced a difficult problem of proof ${ }^{12}$ as well as the usual problems of effecting recovery after judgment. By the last decade of the nineteenth century, it has been said, it had become a "favorite indoor sport" for a merchant to transfer title to his stock in trade and trade fixtures to a good faith purchaser and depart with the consideration. ${ }^{13}$ What was needed was a procedure to permit creditors to move against the seller's

8 Billig, Bulk Sales Laws: A Study in Economic Adjustment, 77 U. of PA. L. REv. 72 (1928); Billig and Smith, Bulk Sales Lazes: A Study in Statutory Interpretation, 38 W. VA. L.Q. 309 (1932); Billig and Branch, Bulk Sales Lazes: Transactions Covered by These Statutes, 39 W. VA. L.Q. 323 (1933), The Problem of Transfers Under Bulk Sales Laws: A Study of Absolute Transfers and Liquidating Trusts, 35 MrCH. L. REv. 732 (1937); 3 WHLIsTon, Sales 467 et seq. (1948); 1 Gienn, Fraudurent Conveyances and Preferences 537 et seq. (1940); Billig, Order Out of Chaos; A Bulk Transfers Article Emerges [1952] Wrs. L. REv. 312 et seq.; 37 C.J.S. 1320.

913 EuIz., c. 5 (1570).

10 Prior to 1939, California law did not go beyond 13 Extz., c. 5 (1570). See Radin, Fraudulent Conveyances in California and the Uniform Fraudulent Conveyance Act, 27 CaLrF. L. Rev. 1 (1938). In 1939, California enacted the UnIForm Fraudulent Conveyance Act, CAL. CIV. CoDE $\$ 3439.01$ et seq.

1113 EuIz., c. 5 (1570). Even under the U.F.C.A., the transfer cannot be set aside if the purchaser acts without knowledge of the seller's intent and gives "fair" consideration. CaL. Crv. CODE \& 3439.04.

12 The courts were occasionally able to assist by inferring knowledge on the part of the buyer from various "badges of fraud." Billig, Bulk Sales Laws: A Study in Economic Adjustment, 77 U. of Pa. L. Rev. 72, 79-80 (1928) ; 1 Glenn, Fraudulent Conveyances and PreferenCes 545 (1940); Moore, Fraudulent Conveyances 257 (1903). Sale of a stock in trade in bulk has $i \mathrm{~m}$ at least one instance been found to be such a badge. In re Baker, 13 F.2d 413 (S.D. Cal. 1926). Cf. Walbrun v. Babbitt, 83 U.S. 577 (1872), cited in Glenn, op. cit. sutpra at 537 , but where sales out of the usual and ordinary course of business were made prima facie evidence of fraud by statute.

13 This was a remark attributed to the first president of the National Association of Credit Men, Billig, Bulk Sales Laws: A Study in Economic Adjustment, 77 U. of PA. L. REv. 72, 75 (1928). 
assets before the transfer occurred. ${ }^{14}$ Consequently, at the urging of the New Orleans Credit Men's Association, Louisiana passed the first bulk sales law in $1896,{ }^{15}$ and the remaining states and the District of Columbia have since followed suit. ${ }^{16}$

The basic function of all of these laws is to provide the seller's creditors with notice of the impending transfer and thus to give them an opportunity to satisfy their claims against the seller from his assets while those assets are still available. The legislature's problem in drafting such a law lies in imposing the necessary notice requirement, with its attendant delay in consummating the transfer, im such a way as to avoid undue interference with legitimate transactions. ${ }^{17}$ It is, of course, a corollary of the notice requirement that a failure to comply therewith results in an infirmity inhering in the transfer, permitting creditors to set it aside. In this sense, the bulk sales law supplements the law of fraudulent conveyances by rendering the noncomplying sale defeasible without regard to the intent of either the buyer or the seller. The notice requirement, however, rather than the corollary creation of a new wrong, has been called the "heart of the bulk sales law."18

There seeins to be little question but that these laws were enacted in each instance through the efforts of the National Association of Credit Men and its local affiliates, ${ }^{10}$ that they were directed primarily at the retail merchant $^{20}$ and were primarily for the protection of the wholesaler. ${ }^{21}$ In their final form, however, as in the case of Califorma's Section 3440.1, they frequently extend their requirements beyond the retail merchant and further afford protection to creditors of the seller whether their claims arise in connection with the busmess or otherwise. ${ }^{22}$

The bulk sales laws of the various states in their present form fall

14 Weintraub and Levin, Bulk Sales Laws and Adequate Protection of Creditors, 65 Harv. L. REv. 418 (1952).

15 Billig, Bulk Sales Laws: A Study in Economic Adjustment, 77 U. of PA. L. Rev. 72, 81-82 (1928).

16 [1952] WIs. I. REv. 312 ns. $2,3$.

17 See 1 Gienn, Fraudulent Convexances and Preterences 539 et seq. (1940). Among other things, this demands an evaluation of the circumstances under which a class of bulk transfers presents a sufficient risk of loss to creditors to justify dclaying all transfers in that class while the required notice is being given. UnLForm Conamercial Code, OfFicial Draft, Text and Comanents Edritron, Comment, Purpose 6, 540 (1952).

$18 I d$., Comment, Purpose 4 at 546.

19 Billig, Bulk Sales Laws: A Study in Economic Adjustment, 77 U. of PA. L. Rev. 72, 101 (1928).

203 Wirliston, SaIes 342 (1948). 102 (1928).

21 Billig, Bulk Sales Laws: A Study in Economic Adjustment, 77 U. of PA. L. REv. 72,

22 See, e.g., In re Mercury Engineering, 68 F. Supp. 376, 382, n.19 (S.D. Cal. 1946) ; [1952] WIS. L. REv. 312, 329 n.49. 
roughly into three categories; $;^{23}$ those in the pattern of the New York statute $^{24}$ (in effect in approximately two-thirds of the states), the Pennsylvania statute ${ }^{25}$ (in effect in approximately one-fourth of the states) and the Connecticut statute ${ }^{26}$ (which is followed only in California, Arizona ${ }^{27}$ and, except as hereinafter noted, Washington ${ }^{28}$ ). Reduced to its barest essentials, the New York statute requires that the buyer obtain from the seller a detailed inventory and cost list of the property to be sold and a sworn list of the creditors of the seller and the amounts owing each, and that the buyer notify personally or by mail the listed creditors and any other creditors of which he has knowledge, a specified number of days prior to the consummation of the sale. The Pennsylvania statute imposes the same basic requirements, but requires in addition that the buyer disburse the purchase money im payment of the claims of creditors listed by the seller or known to the buyer. ${ }^{20}$ The Connecticut statute is similar to Section 3440.1 set forth above. The Washington law was originally in the Connecticut form, ${ }^{30}$ but now requires that the buyer obtain a list of creditors and disburse the purchase money to these creditors in the manner of the Pennsylvania form. The notice requirement, however, remains in the Connecticut form, the seller having the obligation of recording the list of creditors. Since the notice requirement is the most important simgle aspect of the law, Washington may still in this sense be classified with Connecticut. The consequence of failing to comply with the statutory requirements imposed in each case results in the transaction being voidable at the instance of existing creditors, but does not ordinarily affect its validity as between the seller and buyer. ${ }^{31}$

Considering that the enactment of bulk sales laws generally came about through the efforts of the National Association of Credit Men, an interesting question is presented as to what dictated the selection of recordation and ultimately also of publication in California, rather than private notice

${ }^{23}$ See Weintraub and Levin, Bulk Sales Laws and Adequate Protection of Creditors, 65 HARV. L. REV. 418, 420 (1952).

24 N.Y. PERs. Prop. LAW $\S 44$.

2569 PA. Stats. Ann. $\$ 521$ (1931).

26 CONN. Gen. STAT. $\$ 6705$ (1949).

27 ARIz. CODE ANN. § 58-301 (1939).

28 WASH. REV. CODE $§ 63.08$ (1951).

29 In addition, it renders a violation of the statute a misdemeanor and imposes a ninetyday limitation on the time within which a creditor may assert any violation.

30 Wash. Laws, 1901, p. 222.

31 This is true, even thougl the statute may declare the transaction to be "void." Escalle v. Mark, 43 Nev. 172, 183 Pac. 387 (1919); see Weintraub and Levin, Bulk Sales Lanes and Adequate Protection of Creditors, 65 HARv. L. REv. 418 (1952); 37 C.J.S. 1354; 24 Aar. JUR. 356; Note, 30 TEx. L. Rev. 523 (1952); Note, 24 A.L.R.2d 1030 (1952). In a very few instances, violation of the bulk sales law lias been held to result only in a rebuttable presumption that the transaction was fraudulent. See Note, 75 A.L.R. 674 (1931). 
as a means of warning creditors. ${ }^{32}$ Examination of the California legislative annals fails to reveal this reason. Without authoritative assistance, however, an obvious reason suggests itself. The list of creditors required under the New York and Pennsylvania forms, which substantially determines the creditors who will receive notice, is prepared by the seller. As long as the buyer is unaware of omissions from the list, he is protected in most of the states which have adopted this notice requirement. ${ }^{33}$ Thus, the very person whose fraud the statute seeks to guard against is placed in a position to carry out his supposed purpose by omitting creditors' names. ${ }^{34}$ The recordation and publication of notice, on the other hand, while subject to the practical difficulties to the creditor of discovering the existence of the notice, have the virtue of making this element independent of the seller. The fact that four states have continued to utilize this type of notice provision for over half a century strongly suggests that it works to the satisfaction of the creditors for whose benefit the laws operate.

B

\section{EFFECTING COMPLIANCE WITH THE CALIFORNIA BULK SALES LAWS}

The problem of complying with Section 3440.1 is therefore one of giving public notice, commencing at least ten days prior to sale, describing the property to be sold and showing the date and place where the purchase price is to be paid..$^{35}$ Thereafter, the transaction nust occur substantially as described in the notice. ${ }^{36}$ It is thus apparent that the compliance features of this section, as much as any bulk sales law in the country, have resolved the conflicting considerations involved in such a way as to give notice to creditors with the least possible interference with the consummation of the transfer. Although not ordinarily referred to as bulk sales laws, there are in effect in California additional laws desigued to give particular creditors notice of impending bulk transfers. Upon examination, it will be found that

32 Apparently the N.A.C.M. participated in the drafting of a bulk sales law in the form ultimately adopted in New York. Note, 59 Cent. L.J. 114, 115 (1904); see Billig, Bulk Sales Laws: A Study in Economic Adjustment, 77 U. of PA. L. REv. 72, 84 (1928). The first proposed bulk sales law in California was introduced in 1901 at the "instance of the wholesale merchants of San Francisco," S. Jour. 1058 (1901), but, though it passed both houses of the Legislature, it was not signed by Governor Gage. Bulletin of THE NATIONAL Associntion of CREDIT MEN, March 1903, 31-32. A similar bill was again introduced in 1903, and was enacted as Section 3440(2) of the Civil Code of 1901. This law, as amended in various respects, now appears as Section 3440.1 of the Civil Code.

33 E.g., Coach v. Gage, 70 Ore. 182, 138 Pac. 847 (1914); see Billig, Bulk Sales Laws: A Study in Econontic Adjustment, 77 U. of PA. L. Rev. 72 (1928); Billig and Smith, Bulk Sales Laws: A Study in Statutory Interpretation, 38 W. VA.L.Q. 309 (1932); Note, 83 A.L.R. 1140 (1933).

$34 \mathrm{He}$ would do so at the risk, of course, of incurring criminal penalties.

35 See, e.g., Form No. 2074, 2 CowDERX's Forars 523 (6th ed. 1951).

36 Mitchell v. Setzler, 84 Cal. App.2d 716, 191 P.2d 523 (1948). 
these laws ignore the facility of transfer principle inherent in Section 3440.1 and complicate the effectuation of the bulk transfers to which they apply out of proportion to the protection they afford.

The California Sales and Use Tax Law, ${ }^{37}$ which imposes a tax on a retailer's gross receipts from sales of tangible personal property (and a complementary use tax), provides that:

[When a retailer making sales subject to the tax] sells out his business or stock of goods or quits the business, his successors or assigns shall withhold sufficient of the purchase price to cover such amount until the former owner produces a receipt from the board showing that it has been paid or a certificate stating that no amount is due..$^{38}$

If the purchaser of a business or stock of goods fails to withhold purchase price as required, he becomes personally liable for the payment of the amount required to be withheld by him to the extent of the purchase price, valued in money. Within 60 days after receiving a written request from the purchaser for a certificate, or within 60 days from the date the former owner's records are made available for audit, whichever period expires the later, but in any event not later than 90 days after receiving the request, the board shall either issue the certificate or mail notice to the purchaser at his address as it appears on the records of the board of the amount that must be paid as a condition of issumg the certificate. Failure of the board to mail the notice will release the purchaser from any further obligation to withhold purchase price as above provided.$^{39}$

It is obvious that the applicability of these provisions does not precisely coincide with that of Section 3440.1. The sales tax provision would not apply to a bulk sale by one selling items not subject to the tax, ${ }^{40}$ nor to a sale where the buyer is not a business successor. ${ }^{41}$ Concern here will be with the larger area in which both of these laws apply.

The California Unemployment Insurance Code, which provides unemployment and disability compensation financed respectively by "contributions" from employers and employees, the latter to be withheld from wages and remitted by the enuployer, contains similar provisions, as follows:

Any person or employing unit that acquires the organization, trade or busmess, or substantially all the assets thereof, of an employer shall withhold in trust money or other property sufficient in amount, or value to cover the amount of any contributions, imterest and penalties due or unpaid from

37 CAL. REv. AND TAX. CODE $§ 6001$ et seq.

38 Id. at $\$ 6811$.

$39 \mathrm{Id}$. at $\S 6812$.

40 For example, it would not apply to one selling only groceries. Id. at $\S 6359$.

41 People v. Gabriel, 57 Cal. App.2d 788, 135 P.2d 378 (1943), although the language of Section 6812 (and Sales Tax Ruling No. 82, 18 CAt. ADMr. CoDE $\$ 2102$, interpreting it) might have been construed, standing alone, to extend to any "purchaser of a . . . stock of goods." 
such employer until such employer produces a certificate from the department stating that no contributions, interest or penalties are due.

...

Any person or employing unit that fails to withhold money or other property as provided in Section 1731 shall be personally liable for the payment of the contributions, interest and penalties due from the employer up to but not exceeding the purchase price. Upon request of either of the parties to such acquisition the department shall within 30 days issue a certificate, or a statement showing the amount of contribution claimed to be due. The failure to issue a certificate or a statement within the period of 30 days shall be deemed equivalent to the issuance of a certificate stating that no contributions, interest or penalties are due. ${ }^{42}$

The applicability of these sections is not precisely congruent with that of Section 3440.1 or with the noted sales tax provisions, but, where the seller is a retailer with one or more employees, a large area of concurrence exists.

In February 1954, 169 California cities had enacted sales tax ordinances of their own. ${ }^{43}$ Some of these ordinances contain a provision substantially identical to that noted above in the state sales tax law. ${ }^{44}$ Other city ordinances, while not expressly setting forth this type of provision, incorporate by reference, with appropriate changes of terminology, the provisions of the state sales tax law in the form im which they stood on specified dates. ${ }^{45}$

The operation of these tax notice statutes and ordinances is twofold. First, unlike Section 3440.1 which provides for public notice to creditors, they require, in effect, that individual notice be given to the specified tax creditors, a type of notice requirement characteristic of the New York and Pennsylvania forms of bulk sales laws. Second, they make the buyer personally liable up to the amount of the purchase price for the payment of the claims of these specified tax creditors, unless the latter provide appropriate clearance or fail to take any action within the prescribed period. It will be observed that this requirement goes well beyond the Pennsylvania type of requirement that the buyer apply the purchase price to the claims of creditors and requires instead that the specified tax creditors be satisfied ahead of all other creditors. ${ }^{48}$

42 CAL. UNEMPPL. INS. CODE $\$ \$ 1731,1732$.

433 Ingrin, Calmornia Tax Service, City Sares and Use Taxes (1954).

44 E.g., San Francisco Ordinance No. 4537 (series of 1939), \$§ 51, 52; San Diego Ordinance No. 3201 (New Series 1946), $\$ \S 12.13,12.14$.

45 E.g., Oakland Ordinance No. 2264 C.M.S. (1946), § 13; Berkeley Ordinance No. 2789 N.S. (1946), §4. On the other hand, some city sales tax ordinances, while incorporating by reference various provisions of the state law, do not include either Section 6811 or 6812 . For example, LOS ANGELES MUNICIPAL CODE $\$ 21.199$ (j) (1946).

46 California's tax notice statutes are not umique. For example, see ARIz. Code ANN. § 73-317 (1939) ; 69 Pa. Stats. AnN. § 529 (1931), 72. Pa. Stats. AnN. § 1403 (1931); and WASH. REv. CoDE $\$ 83.32 .140$ (1951). These statutes are substantially more onerous from the 
Except for the added complexity in effecting compliance, there would seem to be no fundamental impropriety in superimposing specified individual notice requirements on a bulk sales law otherwise calling only for public notice. ${ }^{47}$ The problems created by the tax notice statutes stem from the fact that each involves a waiting period wholly unrelated in its duration to that required by Section 3440.1 - up to 90 days in the case of sales taxes and 30 days in the case of unemployment insurance contributions, ${ }^{48}$ and froin the priority accorded to the tax creditors.

Since it is virtually certain that statements of tax liability will not be received from taxing authorities within the ten-day period of Section 3440.1, the buyer's first problem is therefore to determine how inuch of the purchase price he will withhold when the ten-day period has expired. Since determination of tax liability may include any tax unpaid during the period of the statute of himitations, as well as interest and penalties thereon, ${ }^{49}$ the cautious buyer, particularly in the small scale transaction, must withhold the entire purchase price. ${ }^{50}$ As already noted, however, the District Court of Appeal in Mitchell v. Setzler ${ }^{51}$ stated that comphance with Section 3440.1 requires that the sale proceed substantially as stated in the notice. On its facts, this case held only that, where no part of the sale described in the notice occurred and a sale pursuant to a further agreement between the parties transpired at a later date, the notice of the first sale could not function to satisfy the requirements of the bulk sales law as to the second sale. Considering that the purpose of Section 3440.1 is to delay the transfer for

standpoint of the buyer than those in California. None provides a maximum time limit within which tax authorities must specify the amount of tax due. The Arizona and Pennsylvania statutes do not expressly limit the buyer's liability to the amount of the purcbase price and the Washington statute specifically obligates the buyer for the full anount of tax claimed to be due without regard to the amount of the purcbase price.

47 It has been suggested under the Illinois bulk sales law (New York form), Ird. REv. STAT. c. $121 \mathrm{I} / 2, \S 78$ et seq. (1941), even in the absence of a special notice requirement, that, since the buyer must notify creditors of which he has knowledge as well as those listed by the seller, this necessarily requires the giving of notice to the United States because of the possible existence of income and social security tax obligations, even though the United States is not a listed creditor, since it is substantially a universal creditor and the buyer is therefore presumed to have knowledge. U.S. v. Goldblatt Bros., Inc., 128 F.2d 576 (7th Cir. 1942), cert. denied, 317 U.S. 662 (1942). This same theory might be extended under the New York form of statute to require notice in every case to more humble tax creditors.

48 The Unemployment Insurance Act originally specified a waiting period identical to that then specified by Section 3440.1. DeERING's GeN. LAws, act 8780 (d), \$ 45.7. The original sales tax notice provision, on the other hand, Cal. Laws 1933, c. 1020, p. 2607, did not embody any time limit.

49 See, for exanple, Sales Tax Ruling No. 82, 18 CaL. AdMr. Code $\$ 2102$.

50 See People v. Buckles, 57 Cal. App.2d 76, 134 P.2d 8 (1943), where the buyer withheld from the purchase price and paid to the state approximately $\$ 400$ shown to be due by the seller's final sales tax return, only to be faced with liability for back taxes, interest and penalty in excess of $\$ 2,700$.

51. 84 Cal. App.2d 716, 191 P.2d 523 (1948). 
a specified period to allow the creditors an opportunity to act, it is difficult to see how the purpose of the statute is thwarted if transfer of title to the buyer occurs on the date specified in the notice, but the purchase price is withheld for an additional period by the buyer. The fact remains, however, that, since Section 3440.1 requires that the notice specify the time when the purchase price will be paid, withholding the entire purchase price until an unspecified later date may constitute a technical violation of Section 3440.1.

Determining upon an amount to be withheld is only the beginning of the buyer's problems. Suppose a case in which the ten-day period of Section 3440.1 has elapsed, the seller has delivered a bill of sale to the buyer and the buyer has paid a portion of the purchase price to the seller, withholding what he deems a reasonable amount under the tax notice statutes. He is then served with a third-party writ seeking debts due the seller, such as a federal levy issued under 26 U.S.C. $\$ 3692$ (1952) or a writ of execution. The buyer clearly has an obligation of some sort to the seller. If pursuant to such a writ, however, he surrenders a portion of the purchase money, he may find himself liable thereafter for state and city tax claims in excess of whatever balance is left in his hands. Although the question appears not to have been specifically resolved judicially, the buyer would seem clearly entitled under these circumstances to take the position that any obligation he has to the seller is subject to the condition precedent of receiving clearances from the taxing authorities and that he therefore has nothing to return under such a writ. ${ }^{52}$

A still further type of priorities question may be presented between the claims, when made, of the Board of Equalization and the Department of Employment if, together, they exceed the amount of the purchase price. ${ }^{.3}$ Under the applicable statutes, each is entitled to payment in full from the buyer up to the amount of the purchase price. In this situation, the Attorney General has advised these two tax authorities to issue certificates of release to the purchaser upon his division of the purchase price between them in proportion to their claims. ${ }^{54}$

In the type of case hypothesized, furthernore, the property to be purchased may well also be subject to encumbrances of one kind or another. Not only does the buyer face the problems of discovering the existence of these liens and determining the order of their priority, but also of resolving

52 Cf. Bunnell v. Basich Bros. Const. Co., 43 Cal. App.2d 538, 111 P.2d 358 (1941) ; Dawson v. Bank of America, 100 Cal. App.2d 305, 223 P.2d 280 (1950); 5 Cax. Jur.2d 606 et seq.; Note, 134 A.I.R. 853 (1941).

53 Both would undoubtedly take precedence over any city tax claims. Note, 167 A.L.R. 640 (1947); 49 AMr. JUR. 273; 81 C.J.S. 637.

54 Letter of January 23, 1953, from the Department of Employment in the files of the writer's firm. Cf. Or. CaL. ATTY. Gen. NS-4613 (November 19, 1942). 
the priority problem which is presented between the liens in the property and the preferred tax claims for which he may personally become liable. In many bulk sale transactions, it is contemplated that existing liens will be discharged out of the purchase price. Under the foregoing statutes and ordinances, however, the buyer is not in a position to devote any specified portion of the purchase price to discharging liens until he ascertains the amount of his liability for the seller's taxes. If, when this amount is ascertained, it, together with the amount of liens, exceeds the purchase price, this dual system of priorities may thus require the satisfaction of obligations greater in amount than the agreed purchase price for the property. If this situation occurs and the seller cannot or will not provide funds to discharge the conflicting claims, the buyer's only practical alternative may well be to back out of the transaction.

In practical operation, bulk sales transfers are frequently handled through an escrow arrangement, rather than directly between the parties themselves. The seller deposits a bill of sale, the buyer deposits the purchase price and the escrow holder's address is specified in the notice as the place of transfer. During the period following notice and prior to payment of the purchase price to the seller, the creditors submit a statement of their claims to the escrow holder, who, after obtaining authorization from the seller, pays these claims when the transfer is consummated.

It would seem a logical extension of this procedure, where the purchase price is inadequate to pay all claims (and the parties authorize it), for the escrow holder to discharge any hens, pay the preferred claims and distribute the balance of the purchase price pro rata among the general creditors who have filed claims with it. Such a procedure has been lauded as an expeditious and inexpensive method of winding up a business. ${ }^{55}$ Yet, in practical experience, escrow holders are reluctant to assume the burden of resolving the problems under discussion. Consequently, when insufficient funds are available from the purchase price to pay all known claims, the escrow holder will ordinarily request the seller to deposit such additional funds as are necessary, and, if this cannot be done, will simply return the bill of sale to the seller and the purchase price to the buyer and refuse to complete the transaction.

\section{C}

\section{PROSPECTIVE CHANGES IN THE BULK SALES LAW}

The introduction of adaptations of the Uniform Commercial Code at the last two regular sessions of the California Legislature ${ }^{56}$ and the fact

55 Harris, The Bulk Sale as a Vehicle for Effecting Out-of-Court Settlement with Creditors, 55 Conar. L.J. 317 (1950). But see Weintraub and Levin, Bulk Sales Laws and Adequate Protection of Creditors, 65 HARv. L. REv. 418 (1952).

561951 Session, A.B. 588; 1953 Session A.B. 1232. Neither bill progressed beyond initial reference to committee. 
that interim legislative study has now been proposed for this code ${ }^{57}$ portend a substantial revision of Section 3440.1, for the Uniform Commercial Code contains a separate article dealing with transfers in bulk which would supersede this section. ${ }^{58}$ The consensus appears to be that the uniform bulk transfers article is sound and well drafted. ${ }^{59}$ As a law specifically for use in California, however, it may bear some further consideration.

Preliminarily, it should be noted that transactions falling within the purview of bulk sales laws ordinarily involve the application of the law of only one state. Hence, the desirability of uniformity underlying most of the Unifornn Commercial Code, predicated on interstate activity does not apply with equal force to the bulk transfers article. ${ }^{60}$ Analysis of this article must, therefore, be less in terms of its desirability as a uniform law than in terms of its acceptability as a noodel law.

Early drafts of the bulk transfers article followed the Pennsylvania forni of bulk sales law in the respect that they contained a provision imposing on the buyer the duty of applying the proceeds of the sale to the payment of the seller's creditors. ${ }^{61}$ The bulk sales article of A.B. 588, introduced at the 1951 session of the California Legislature, was in this form. ${ }^{62}$ The requirement of application of the proceeds by the buyer proved to be so controversial because of the resulting burden imposed on the buyer, however, that the official draft, conpleted in 1952, nidicates the adoption of this provision to be optional. ${ }^{63}$ A.B. 1232 , nitroduced at the 1953 session, was basically in the forn of the official draft, omitting the requirement that the buyer apply the proceeds to the payment of the seller's creditors. In this respect A.B. 1232 was consistent with the philosophy of Section 3440.1 in balancing the facility of transfer and the maximum protection of creditors somewhat in favor of the fornier consideration.

The change of greatest significance in California proposed by the adoption of the bulk transfers article is in the manner of giving notice to creditors. ${ }^{64}$ The present public notice provisions of Section 3440.1, and the experience of over half a century in the utilization of public notice, would

57 Cal. Laws 1954 (First Extra.) Sess., Res. c. 8.

58 Uniforar Comocerciat Code, Offictat Draft, Text and Comments Edition, Article 6 (1952).

59 [1952] Wis. L. Rev. 331 ; Miller, The Effect of the Bulk Sales Article on Existing Commercial Practices, 16 Law \& ConteMcP. ProB. 267 (1951).

60 Beutel, The Proposed Uniform Commercial Code as a Problem in Codification, 16 LAW \& Contemp. Prob. 141, 160 (1951), for this reason characterizes the bulk transfers article as "of no particular significance."

61 For example, see Article 7 of the draft of May 1949.

621951 Session, A.B. 588, Article 10. See particularly \$10106.

63 Uniforar Commerctal Code, Offictal Draft, Text and Comments Edition, \& 6-106 (1952).

64 Id. at § 6-107. 
be abandoned completely in favor of notice given in person or by mail to creditors listed by the seller or otherwise known to the buyer. ${ }^{65}$ For the reasons already discussed, ${ }^{66}$ the desirability of this change seems doubtful. ${ }^{67}$

The uniform article proposes a number of changes which would render it inapplicable to many transactions covered by Section 3440.1 . A bulk sale would be defined as a transfer "in bulk," business of a "major part" of the "inventory" of an enterprise "whose principle business is the sale of inerchandise from stock, mcluding those who manufacture what they sell." would be covered only where a "substantial" part thereof is transferred "in connection with a bulk transfer of inventory."70 The term "major" (as against "substantial") seems clearly to require a sale of more than one-half of the stock in trade to render the act applicable, thus ruling out lesser transactions which do not properly call for bulk sales law protection. ${ }^{71}$ Early drafts of the Code also included, as subject transfers, any transfer leaving the seller without adequate capital, exclusive of the consideration for the property transferred, for the "regular" conduct of his business. This definition appeared in A.B. 588. ${ }^{72}$ The final draft of the bulk transfers article substituted for this standard the somewhat more definite standard of a transfer, which, exclusive of the consideration therefor, leaves the seller unable to meet this obligations as they mature.$^{73}$ Undoubtedly, because of

$65 I d$. at $\$ \S 6-105,6-107$; 1951 Session, A.B. 588, § 10107; 1953 Session, A.B. 1232, § 16107. The waiting period would be ten days before the goods are "moved," or the buyer takes possession or the interest of the seller passes to the buyer, whichever occurs first. Failure to give the required notice would render the transfer "ineffective against any creditor of the transferor." This phrase seems intended to adopt the existing interpretation of "fraudulent and void" in Section 3440.1, and is a distinct improvement in terminology. See note 31 supra.

66 Supra note 34.

67 It should be noted that a change in the notice provision of the bulk transfers article would in no way disrupt the relationship of that article to the balance of the Uniform Code.

68 The retention of the term "in bulk" seems to be explained only by the historic association of this tern with the type of transaction. See Miller, The Effect of the Bulk Sales Article on Existing Commercial Practices, 16 LaW \& Contemp. Prob. 267 (1951).

69 Untforar Comamercial Code, Official Draft, Text and Comaments Edition $\$ 6-102$ (1952) ; 1951 Session, A.B. 588, § 10102; 1953 Session, A.B. 1232, §16102. It may be that inclusion of transfers by manufacturers would be an expansion of the scope of Section 3440.1 . While the language of Section 3440.1 could well be construed to include inanufacturers, it is suggested in Shasta Lumber Co. v. McCoy, 85 Cal. App. 468, 259 Pac. 965, 967 (1927), that it does not. $C f$. Mill and Logging Supply Co. v. West Tenino Lumber Co., 265 P.2d 807 (Wash. 1954), concluding that manufacturers are not covered by the Washington bulk sales law.

70 Uniforar Comanercial Code, Ofeicial Draft, Text and Comanents Editron § 6-102 (1952); 1951 Session, A.B. 588, § 10102; 1953 Session, A.B. 1232, § 16102.

71 See note 3 supra.

721951 Session, A.B. 588, § 10102.

73 Unirorar Comanercial Code, Official Draft, Text and Comments Edition § 6-102 (1952). A bulk transfer of a stock in trade by an insolvent for a present fair consideration in coinpliance with the governing bulk sales law does not constitute an act of bankruptcy. Weintraub and Levin, Bulk Sales Laws and Adequate Protection of Creditors, 65 HARv. L. REv. 418 (1952). See also Harris, The Bulk Sale as a Vehicle for Effecting Out-of-Court Settlement with Creditors, 55 Cosar. X.J. 317 (1950). 
the uncertainty any such standard creates in determining its applicability to any specific transfer, the editorial board has recommended, ${ }^{74}$ and the national conference has approved, ${ }^{75}$ the omission of this concept entirely, and, accordingly, neither of these definitions appeared in A.B. 1232. ${ }^{70}$

The definition of a covered transfer would exclude service enterprises such as those now specifically covered by Section 3440.1. The drafters explain this omission as follows: "While some bulk sales risk exists in the excluded busmesses, they have in comnion the fact that unsecured credit is not conmonly extended on the faith of a stock of merchandise." ${ }^{\prime 77}$ This explanation assumes that, where there is a stock of nierchandise, it does constitute a basis upon which unsecured credit is extended. This is doubtful except in the general sense that creditors may consider all of a potential debtor's assets before extending him credit. It would seenı sounder to recognize the bulk sales law as resting on a public policy favoring paynient of creditors and iniplenienting this policy where the debtor's business assets consist primarily of readily saleable property. This analysis tends to support the exclusion of concerns whose worth stems primarily froin the rendition of services. Certainly the inclusion of some service enterprises and the exclusion of all others, as under Section 3440.1 , is difficult to justify.

The proposed new law would also himit the operation of Section 3440.1 in the field of mortgages and other security transfers. ${ }^{78}$ Section 3440.1 expressly covers mortgages of "fixtures or store equipment" in specified

74 Recommendations of the editorial board for cbanges in the text and comments of the Unifora Commercial Code, Offictat Draft, Text and Comments Edition 9 (June 1, 1953).

75 Uniforar Laws Annotated, Uniform Commercial Code, Changes in Text and ComMENTS (1953).

76 Cf. CAL. Crv. Code $\$ 3439.05$, under which a transfer without a "fair" consideration by a person engaged in business where the property remaining in his hands after the transfer is "unreasonably small capital," is fraudulent, without regard to the intent of the transferor, as to creditors "during the continuance of" the busimess.

77 Uniform Compmerctal Code, Official Draft, Text and Conoments Edition, Comment, Purpose 2, p. 541 (1952).

78 Also excluded from coverage would be (a) general assignments for the benefit of all creditors, (b) sales under judicial supervision, (c) sales on dissolution of a corporation of which creditors receive similar advance notice, (d) transfers to a solvent person maintaining a known place of business in the state who assumes the transferor's debts and to a business successor who acquires no interest superior to creditors' claims and who assumes the transferor's debts, and (e) transfers of property exempt from execution. UNLFORMC COMMIERCIAL Code, Officiar Draft, Text and Comarents Edition § 6-103 (1952). Of these, (a) and (b) at least are exempt under Section 3440.1. See Brainard v. Fitzgerald, 3 Cal.2d 157, 44 P.2d 336 (1935); Cooley v. Brennan, 102 Cal.App.2d 952, 228 P.2d 104 (1951). To these listed exclusions, the national conference has added transfers in settlement of a security interest. Recommendations of the editorial board for changes in the text and comments of the UNIFORM Conarercial Code, Official Draft, Text and Conanents Edition 10 (June 1, 1953); Untrorar Laws annotated, Uniform Comanercial Code, Changes in Text and Commants 12 (1953). 
cases $^{79}$ and has also been construed to include transfers of security interests in the stock in trade insofar as such transfers are valid at all in California. ${ }^{80}$ The official draft of the bulk transfers article excluded transfers "for the sole purpose of giving security for the repayment of new value extended to the transferor," but included transfers of security interests for the purpose of securing an existing obligation. ${ }^{81}$ The purpose of including this latter class of security transfers at all was not to give creditors an opportunity to act to prevent the transfer, but rather to enable them to set the transfer aside where it constituted a preference under the Bankruptcy Act. ${ }^{82}$ Consistently with this consideration, the bulk transfers article required only that notice of such a transfer be given at the time of the transfer rather than ten days prior thereto. This provision appeared in A.B. 588. Since this purpose is beyond the essential purpose of a bulk sales law and since security transactions are dealt with $\mathrm{m}$ Article 9 of the Uniform Code, ${ }^{83}$ the national conference has approved the removal of such transfers from this article entirely. ${ }^{84}$

Since Article 9 does not provide for any notice in advance of the transfer, creditors would thus receive much less protection from the creation of security interests than is presently provided. ${ }^{85}$ While a majority of the various states' bulk sales laws do not apply to security transfers, ${ }^{86}$ such transfers seein to present, at least where for a new consideration, the same bulk sales risk as an outright conveyance. ${ }^{87}$ If, therefore, a transferor is of

79 Cf. Citizens Nat. Trust \& Savings Bank v. Gardner, 161 F.2d 530 (9th Cir. 1947) (Section 3440.1 not applicable to purchase money mortgage of fixtures); In re Sassard \& Kimball, 45 F.2d 449 (9th Cir. 1930) (persons becoming creditors of mortgagor of fixtures after recordation of mortgage under CAL. Crv. CoDE $\$ 2957$ cannot assert failure to comply with bulk sales law requirements).

80 A merchant's stock in trade may not be mortgaged, CAL. Crv. Code $\$ 2955$. See Woodruff v. Laugliarn, 50 F.2d 532 (9th Cir. 1931). It may be pledged, but the pledge is a "transfer" under Section 3440.1, and inust therefore be made in compliance with that section. In re Convisser, 6 F.2d 177 (9th Cir. 1925) ; Markwell \& Co. v. Lynch, 114 F.2d 373 (9th Cir. 1940).

81 Uniforar Comanerciat, Code, Offictal Draft, Text and Comments Edition § 6-102(2) (1952).

82 Id. at Comment, Purpose 2, p. 543; Comment, Purpose 4, p. 546.

83 Id. at Article 9.

84 Untrorm Laws Annotated, Untrorm Coamercial Code, Changes in Text and Com3rENTS 12 (1953); see recommendations of the editorial board for clianges in the text and comments of the Untrorm Comamercial Code, Offictal Draft, Text and Comments EdiTroN 10, 11 (June 1, 1953).

85 Under Article 9, a valid transfer may be made of a security imterest in a stock of merchandise without transfer of possession. \$ 9-303 (2) (a). However, transferees in the ordinary course of business would take free of any such security interest and transferees in bulk would take free of any such interest not previously "perfected" ("filed" as required). Creditors, loowever, would take subject thereto unless they acquire liens of their own prior to perfection of the security interest.

86 Billig and Smith, Bulk Sales Laws: Transactions Covered by These Statutes, 39 W. VA. L.Q. 323 (1933).

87 See In re Convisser, 6 F.2d 177 (9th Cir. 1925). 
a class whose outright transfers are deemed appropriate for coverage, sound basis appears for mcluding his security transfers as well.

The balance of the uniform article seems less worthy of comment here. ${ }^{88}$ Its protection would extend to creditors at the time of the bulk transfer even though their claims were then unliquidated ${ }^{89}$ but bona fide purchasers from a transferee would take free of any defect resulting from a violation of the law. ${ }^{90}$ Any creditor intending to assert a violation of the law would be required to act within six months unless the transfer was concealed. ${ }^{91}$

\section{CONCLUSION}

From the foregoing, it is apparent that the legislative study which is to be given the Uniform Commercial Code nuay profitably devote some attention to the bulk transfers article. In addition, while considering a revision of Civil Code Section 3440.1, it would seem particularly appropriate to give consideration to a revision of the tax notice statutes which have been discussed. At this writing, no such consideration has reached the legislature.

Indeed, much is to be said for the outright repeal of these tax notice statutes. (Similar action by mumcipal legislative bodies would, of course, be necessary as to the tax notice ordinances.) If they provided a necessary remedy to assure the collection of taxes from close-out transactions generally, then perhaps the problems they create could be justified in a number of small transactions as a necessary administrative evil. This is not the case, however. Each of the taxing authorities has extensive summary remedies for proceeding against the seller.$^{92}$ Among these remedies, the Board of Equalization has the important power to require of sellers making sales

88 See California annotations to the Proposed UnIForar Commercial Code 68 el seq. (1952) for a general comparison of the provisions of the bulk transfers article with existing California law.

89 Uniforar Comanercial Code, Officlal Draft, Text and Comments Edition §6-109(1) (1952).

$90 I d$. at $\S 6-110$.

91 Id. at \$6-111. Special provision would also be made for auction sales, the notice (and application of proceeds) obligation being placed on the auctioneer, and noncompliance resulting in liability of the auctioneer to the seller's creditors up to the "net proceeds of the auction." Id. at § 6-108.

92 In the case of the sales tax, for example, the Board of Equalization can sue and attach (CAL. Rev.\& TAX. CODE $\$ 6711$ et seq.) ; it may obtain a summary judgment ex parte and execute on the seller's property ( $\$ 6736$ et seq.); and it may file the judgment with the county recorder, whereupon it becomes a lien on all real property of the tax debtor in the county ( $\$ 6757)$; it may simply seize the tax debtor's property and sell it to satisfy a claimed delinquency without judicial proceedings $(\$ 6796$, et seq.) ; it may serve a notice to withhold, effective for sixty days, on any person loolding personal property or credits of the tax debtor ( $\$ 6702$ ). Many of the cities having sales taxes have adopted by reference these provisions of the state law [for example, Oakland Ordinance No. 2264 C.M.S. $\$ 13$ (1946)], or have tleeir own similar provisions [for example, San Diego Ordinance No. 3201, New Series, $\$ 12.6$ et seq. (1946)]. The Department of Employment also has somewhat similar summary procedures available to it. CAL. UNEMPL. INS. CODE $\S \S 1126-1140,1703,1755-1758,1785-1787,1815-1817,1852-1854$. 
subject to the sales tax the filing of a bond in the minimum amount of $\$ 10,000$ to secure collection of taxes whenever it deems such protection "necessary." In fact, the Board has expressed a preference for bonding as a method of assuring full tax payment at a minimum of administrative cost, and in 1950 seventy percent by number of sales tax accounts were required to be bonded. ${ }^{94}$ Assuming this power has been exercised as to the accounts most likely to present a threat of tax loss, the problem to which Revenue and Taxation Code Sections 6811 and 6812 are directed would seem already to have been met. ${ }^{95}$ Some of the cities have this same power. ${ }^{96}$ The Department of Employment does not have this authority, but may require of employers the deposit of such security as is deemed "necessary" after the Department has made a jeopardy assessment. ${ }^{27}$

Short of outright repeal, these sections might be incorporated into Section 3440.1 as a requirement that specific notice be given to designated taxing authorities at the time public notice is being given to general creditors. At the very least, the concurrent impact of the various laws which have been discussed should be recognized by the adoption of a umiform waiting period. Thus, for example, if each of the statutes required a thirtyday advance notice of sale, the buyer would be in a position to consummate the transaction at the expiration of that period, secure in the knowledge that he would not thereafter become liable for the seller's obligations.

93 CaL. Rev. \& TAX. Code $\$ 6701$.

97 Report of the Senate Internm Conmmttee on State and Local Taxation, Part 3, p. 57 (1951).

95 $C f$. statistics noted in text at note 4 supra.

96 Oakland Ordinance No. 2264 C.M.S. $\$ 13$ (1946) ; San Diego Ordinance No. 3201, New Series, $\S 12.6$ (1946); San Francisco Ordinance No. 4537, $\$ 48$ (Series of 1939).

97 Cat. Unempl. Ins. Code $§ 1138$. 